\title{
Comparison of transition temperature range and phase transformation behavior of nickel-titanium wires
}

\author{
Yu-Hyun Lee, DDS, PhD, ${ }^{\text {a }}$ Bum-Soon Lim, BA, PhD, ${ }^{\mathrm{b}}$ Yong-Keun Lee, DDS, PhD, ${ }^{\mathrm{c}}$ Cheol-We Kim, DDS, PhD, \\ Seung-Hak Baek, DDS, $\mathrm{PhD}^{\mathrm{e}}$
}

\begin{abstract}
Objective: The aim of this research was to evaluate the mechanical properties (MP) and degree of the phase transformation (PT) of martensitic (M-NiTi), austenitic (A-NiTi) and thermodynamic nickel-titanium wire (T-NiTi). Methods: The samples consisted of $0.016 \times 0.022$ inch M-NiTi (Nitinol Classic, NC), A-NiTi (Optimalloy, OPTI) and T-NiTi (Neo-Sentalloy, NEO). Differential scanning calorimetry (DSC), three-point bending test, X-ray diffraction (XRD), and microstructure examination were used. Statistical evaluation was undertaken using ANOVA test. Results: In DSC analysis, OPTI and NEO showed two peaks in the heating curves and one peak in the cooling curves. However, NC revealed one single broad and weak peak in the heating and cooling curves. Austenite finishing $\left(A_{f}\right)$ temperatures were $19.7^{\circ} \mathrm{C}$ for OPTI, $24.6^{\circ} \mathrm{C}$ for NEO and $52.4^{\circ} \mathrm{C}$ for NC. In the three-point bending test, residual deflection was observed for NC, OPTI and NEO. The load ranges of NC and OPTI were broader and higher than NEO. XRD and microstructure analyses showed that OPTI and NEO had a mixture of martensite and austenite at temperatures below Martensite finishing $\left(\mathrm{M}_{\mathrm{f}}\right)$. NEO and OPTI showed improved MP and PT behavior than NC. Conclusions: The mechanical and thermal behaviors of NiTi wire cannot be completely explained by the expected degree of PT because of complicated martensite variants and independent PT induced by heat and stress.

(Korean J Orthod 2010;40(1):40-49)
\end{abstract}

Key words: Transition temperature range, Phase transformation, Ni-Ti wires

\section{INTRODUCTION}

Nickel-titanium (NiTi) wire has been widely used in the orthodontic field due to its shape memory effect,

\footnotetext{
${ }^{\text {a }}$ Private Practice.

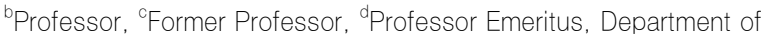
Dental Biomaterials Science, Dental Research Institute, School of Dentistry, Seoul National University.

${ }^{e}$ Associate Professor, Department of Orthodontics, School of Dentistry, Seoul National University.

Corresponding author: Seung-Hak Baek.

Department of Orthodontics, School of Dentistry, Dental Research Institute, Seoul National University, 28, Yeongeon-dong, Jongno-gu, Seoul 110-768, Korea

+82 22072 3952; e-mail,drwhite@unitel.co.kr.

Received May 14, 2009; Last Revision October 19, 2009 :

Accepted October 21, 2009.

DOl:10.4041/kjod.2010.40.1.40
}

super-elasticity and good biocompatibility. ${ }^{1}$ There are three microstructural phases in the NiTi alloys ie. the austenitic phase, the high-temperature and low-stress form; the martensitic phase, the low-temperature and high-stress form; and the R-phase, an intermediate phase between martensite and austenite transformation. ${ }^{2}$ The relative proportion of the austenitic and martensitic phases within transformation temperature range (TTR) seems to play an important role in the mechanical characteristics of NiTi wire. ${ }^{2-4}$

When NiTi wire is ligated to brackets on misaligned teeth in a temperature-fluctuant oral 0environment, slight thermal change can considerably modify the load level of NiTi wire. ${ }^{5,6}$ A discrepancy between transformation characteristics and related mechanical properties of NiTi wires has also been reported..$^{7-10}$ 
Several commercially available NiTi wires are available such as the work-hardened martensitic type (MNiTi), superelastic austenitic (A-NiTi) and thermodynamic (T-NiTi). Although M-NiTi wires can exhibit shape memory characteristics, their TTR does not seem to be clinically relevant for this property to be used for orthodontic treatment. ${ }^{11}$ Burstone et al. ${ }^{12}$ and Miura et al. ${ }^{13}$ introduced A-NiTi for superelasticity. More recently, T-NiTi wires have been developed for shape memory effect as well as superelasticity. ${ }^{14}$ However, these NiTi wires exhibit unexpected mechanical properties under stepwise temperature changes. ${ }^{10,15}$ Therefore, the purpose of this study was to evaluate the mechanical properties and degree of the phase transformation of commercially available M-, A- and TNiTi wires under conditions of controlled temperature.

\section{MATERIAL AND METHODS}

Three types of $0.016 \times 0.022$ inch commercially available NiTi wires, M-NiTi (Nitinol Classic, 3MUnitek, Monrovia, CA, USA; NC), A-NiTi (Optimalloy, Jinsung Medical, Seoul, Korea; OPTI), and T-NiTi (Neo Sentalloy, GAC, Tokyo, Japan; NEO) were used in this study (Table 1).

Differential scanning calorimetry (DSC) analysis

Transformation temperatures were measured using DSC 204 (Netzche, Germany). Specimens of each wire with the same length $(4 \mathrm{~mm})$ were sealed in an aluminum cell and placed into the measuring chamber, which was filled with argon gas. $\alpha$-alumina was used as the reference material. The scanning temperature ranged from -20 to $100^{\circ} \mathrm{C}$ at $5^{\circ} \mathrm{C} / \mathrm{min}$. The measure- ments were taken three times and were statistically analyzed using analysis of variance (ANOVA).

\section{Three-point bending test}

Three-point bending tests were performed using a universal testing machine (Instron 4465, UK) in a temperature-controlled water bath. The span length between the two supports was $14 \mathrm{~mm}$. A bending load was applied to the wire specimen at a rate of $1.0 \mathrm{~mm} /$ minute to give a $2.0 \mathrm{~mm}$ deflection, and the load was subsequently removed at the same rate. The wire deflection was carried out at four different temperatures $\left(0,20,37\right.$ and $\left.60^{\circ} \mathrm{C}\right)$. The measurements were taken three times and were statistically analyzed by ANOVA.

\section{Microstructure examination}

The specimens were embedded in a self-curing resin and were electropolished for $6-7$ minutes in a $\mathrm{CH}_{3} \mathrm{COOH}$ and $\mathrm{HClO}_{4}$ solution. The final surface was prepared by etching with a mixture of hydrofluoric acid (48\% concentration), nitric acid (70\% concentration), and deionized water in proportions of $1: 4$ : 10 by volume to reveal the grain boundary microstructure. Microstructure was examined using the metallurgy microscope (IEM405, Zeiss, Germany).

X-ray diffraction (XRD) analysis

XRD was used to identify the crystal structure and relative portion of the austenite and martensite at various temperatures. An XRD Image Processor (DIP 2030, MAC science, Japan) was used with $\mathrm{Cu}-\mathrm{K}_{\alpha}$ radiation at $40 \mathrm{KV}$ and $80 \mathrm{~mA}$ for the low temperature measurements $\left(-20,5\right.$ and $\left.20^{\circ} \mathrm{C}\right)$. In a pilot study, the

Table 1. Nickel-Titanium (NiTi) orthodontic wires used in this study

\begin{tabular}{rllll}
\hline Species & Code & Brand name & Batch number & Manufacturer \\
\hline \hline M-NiTi & NC & Nitinol classic & W5084 & 3M Unitek, U.S.A. \\
A-NiTi & OPTI & Optimalloy & NO20805-016 & Jinsung Meidcal, Korea \\
T-NiTi & NEO & Neo sentalloy & E589 & Tomy International, Japan \\
\hline
\end{tabular}

M-NiTi means work-hardened martensitic type; A-NiTi, super-elastic austenitic type; T-NiTi, thermodynamic type. 
XRD results at $0^{\circ} \mathrm{C}$ where the three-point bending test was performed could not be differentiated with that of the $5^{\circ} \mathrm{C}$ data. Therefore, the XRD test was performed at $-20^{\circ} \mathrm{C}$. The sampling stage was oscillated from 0 to $60^{\circ}, 2 \theta$ in 0.01 degree steps to minimize the effect of the preferred orientation of wires. For the phase distribution analysis of martensite (002 peak) and austenite (110 peak) wires, FWHH (full width at half height) was compared. Powder XRD (D5005, Bruker, Germany) was used for the higher temperature measurements $\left(37\right.$ and $\left.60^{\circ} \mathrm{C}\right)$. The temperature was controlled by an electrothermic system and liquid nitrogen.

\section{RESULTS}

In the definitions of the transformation temperatures such as $\mathrm{M}_{\mathrm{s}}, \mathrm{M}_{\mathrm{f}}, \mathrm{A}_{\mathrm{s}}$, and $\mathrm{A}_{\mathrm{f}}, \mathrm{M}$ means martensite; $\mathrm{A}$, austenite; $\mathrm{S}$, starting temperature; and $\mathrm{f}$, finishing temperature, respectively.
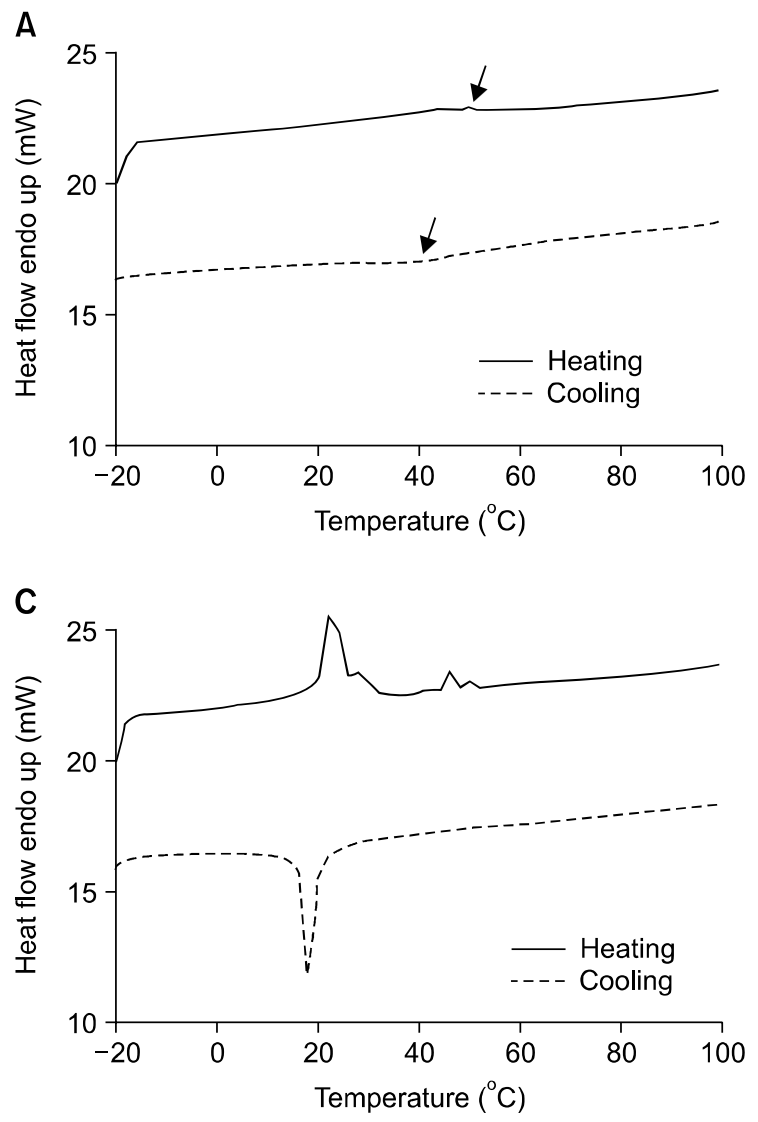

DSC analysis

For NC (M-NiTi type), one single broad and weak peak was observed in the heating and cooling curves, respectively (Fig 1A). However, OPTI (A-NiTI type) and NEO (T-NiTi type) exhibited two endothermic peaks in the heating curves. It indicates that there may be an intermediate phase (R-phase: rhombohedral phase) during transformation. One exothermic peak (around 15 $-18^{\circ} \mathrm{C}$ ) observed on the OPTI and NEO in the cooling curves could be considered as the reverse transformation from austenite phase to martensite phase (Fig 1B and C).

The TTRs for the three specimens were statistically different $(p<0.05$, Table 2$)$. $\mathrm{M}_{\mathrm{s}}$ in the cooling process of NEO (T-NiTi type, $20.2^{\circ} \mathrm{C}$ ) was higher than OPTI (A-NiTi type, $17.0^{\circ} \mathrm{C}$ ). Various $\mathrm{A}_{\mathrm{f}}$ were found; $19.7^{\circ} \mathrm{C}$ for OPTI (A-NiTi type), $24.6^{\circ} \mathrm{C}$ for NEO (TNiTi type) and $52.4^{\circ} \mathrm{C}$ for NC (M-NiTi type), respectively (Table 2).

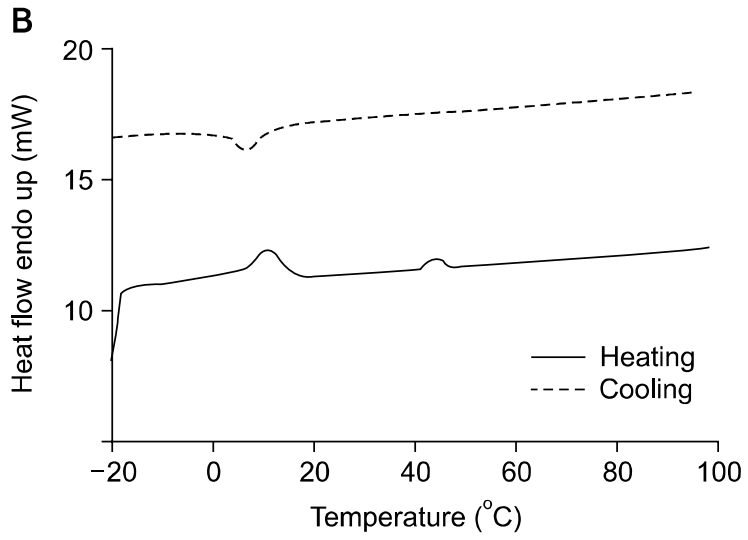

Fig 1. Heating and cooling curves of nickel-titanium with differential scanning calorimetry (DSC). A, Nitinol Classic (NC, 3M-Unitek, Monrovia, CA, USA; martensitic(M)- NiTi type); B, Optimalloy (OPTI, Jinsung Medical, Seoul, Korea; austenitic(A)-NiTi type); C, Neo Sentalloy (NEO, GAC, Tokyo, Japan; thermodynamic(T)-NiTi type). Arrows in $\mathbf{A}$ means broad and weak peaks occurred during the heating and cooling cycle, respectively. Two peaks in the heating curves of $\mathbf{B}$ and $\mathbf{C}$ indicates the existence of $\mathrm{R}$ (rhombohedral) phase. 
Table 2. Comparison of the peak temperature during heating and cooling curves according to differential scanning calorimetry (DSC) analysis

\begin{tabular}{|c|c|c|c|c|c|c|c|c|c|c|c|c|c|}
\hline \multirow[b]{2}{*}{ Species } & \multirow[b]{2}{*}{ Code } & \multicolumn{6}{|c|}{ Heating } & \multicolumn{6}{|c|}{ Cooling } \\
\hline & & $\begin{array}{l}\mathrm{A}_{\mathrm{s}} \\
\left({ }^{\circ} \mathrm{C}\right)\end{array}$ & $\begin{array}{c}\text { Peak } \\
\left({ }^{\circ} \mathrm{C}\right)\end{array}$ & $\begin{array}{c}\mathrm{A}_{\mathrm{f}} \\
\left({ }^{\circ} \mathrm{C}\right)\end{array}$ & $\begin{array}{l}\mathrm{TTR}^{*} \\
\left({ }^{\circ} \mathrm{C}\right)\end{array}$ & $\begin{array}{c}\Delta \mathrm{H} \\
(\mathrm{mJ})\end{array}$ & $\begin{array}{c}\Delta \mathrm{Q} \\
(\mathrm{J} / \mathrm{g})\end{array}$ & $\begin{array}{l}\mathrm{M}_{\mathrm{S}} \\
\left({ }^{\circ} \mathrm{C}\right)\end{array}$ & $\begin{array}{c}\text { Peak } \\
\left({ }^{\circ} \mathrm{C}\right)\end{array}$ & $\begin{array}{l}\mathrm{M}_{\mathrm{f}} \\
\left({ }^{\circ} \mathrm{C}\right)\end{array}$ & $\begin{array}{l}\mathrm{TTR}^{*} \\
\left({ }^{\circ} \mathrm{C}\right)\end{array}$ & $\begin{array}{l}\Delta \mathrm{H} \\
(\mathrm{mJ})\end{array}$ & $\begin{array}{c}\Delta \mathrm{Q} \\
(\mathrm{J} / \mathrm{g})\end{array}$ \\
\hline M-NiTi & $\mathrm{NC}$ & $(48.5)$ & $(50.5)$ & (52.4) & (3.9) & (1.8) & $(41.2)$ & (55.4) & $(40.1)$ & (8.3) & $(47.1)$ & $(-2.4)$ & $(-53.9)$ \\
\hline $\mathrm{A}-\mathrm{NiTi}$ & OPTI & 10.5 & 15.3 & 19.7 & 9.2 & 3.4 & 76.0 & 17.0 & 11.3 & 6.0 & 11.0 & -2.9 & -66.7 \\
\hline $\mathrm{T}-\mathrm{NiTi}$ & NEO & 20.6 & 23.0 & 28.0 & 7.4 & 5.8 & 137.5 & 20.2 & 18.1 & 16.0 & 4.2 & -4.5 & -106.0 \\
\hline
\end{tabular}

ANOVA test was done. "Means $p<0.05$; M, martensite; A, austenite; S, starting temperature; f, finishing temperature; TTR, transformation temperature range; $\Delta \mathrm{H}$, transition enthalpy; $\Delta \mathrm{Q}$, transition energy; $\mathrm{M}-\mathrm{NiTi}$, work-hardened martensitic type; A-NiTi, super-elastic austenitic one T-NiTi, thermodynamic one. ( ): not in the graphs, but was pitched with peak-picfing function.
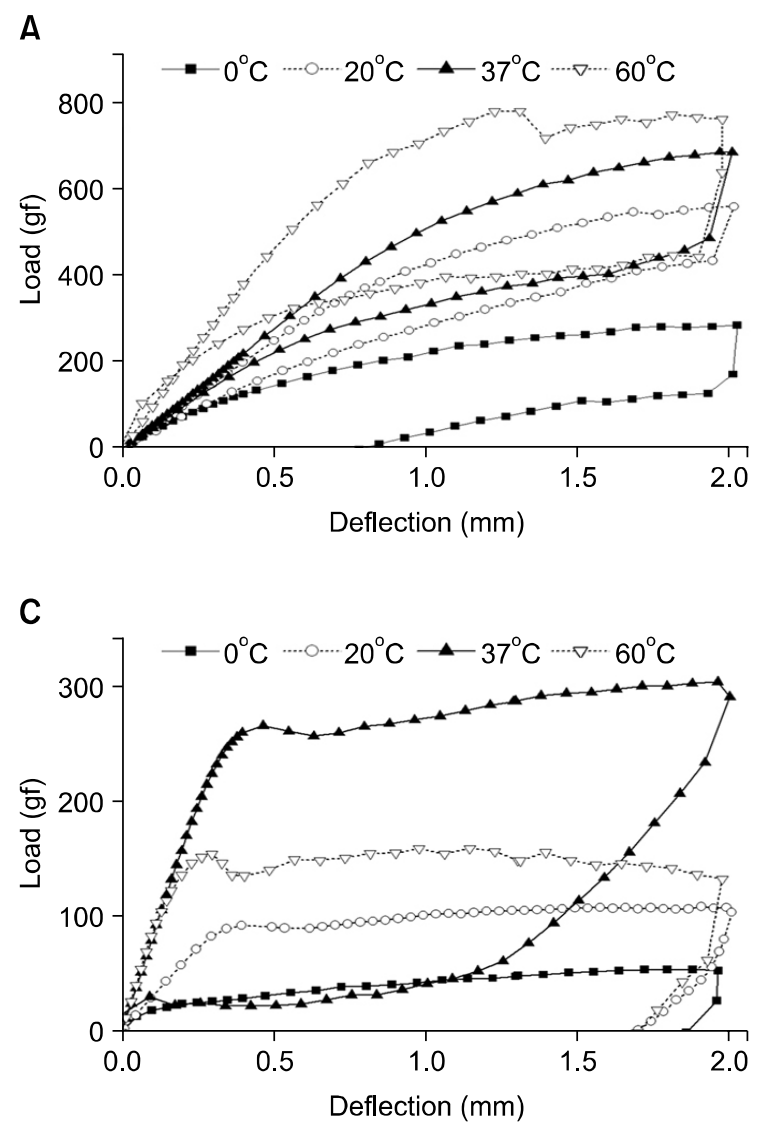

Three-point bending test

In NC (M-NiTi type), the superelasticity loop appeared at $60^{\circ} \mathrm{C}$ (Fig $2 \mathrm{~A}$ and Table 3). Total recovery $(\delta=0)$ was observed at $20^{\circ} \mathrm{C}$ and $37^{\circ} \mathrm{C}$ (Table 3),
B

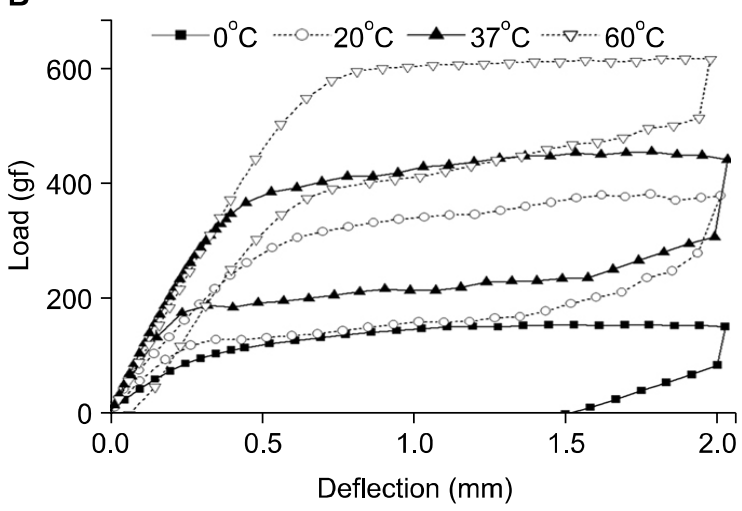

Fig 2. Load-deflection curves of the nickel-titanium wires with changes in temperature. A, NC (M-NiTi type), B, OPTI (A-NiTi type), C, NEO (T-NiTi type).

where the superelasticity loop did not appear (Fig 2A). Partial recovery at $0^{\circ} \mathrm{C}(\delta=0.8 \pm 0.02$, Table 3$)$ might be an expression of the plastic deformation in the martensite phase.

In OPTI (A-NiTI type), total recovery was observed 
Table 3. Comparison of the mechanical properties according to a function of temperature

\begin{tabular}{|c|c|c|c|c|c|c|c|}
\hline Species & Code ? & Temp. $\left({ }^{\circ} \mathrm{C}\right)$ & $\alpha$ load（gf) & $\beta$ load (gf) & $\gamma$ load (gf) & $\delta$ load (gf) $\sigma$ & deflection $(\mathrm{mm})$ \\
\hline \multirow[t]{4}{*}{ M-NiTi } & $\mathrm{NC}$ & 0 & $79.8 \pm 5.05^{\dagger}$ & $300.5 \pm 10.33^{\dagger}$ & $121.9 \pm 24.70^{\dagger}$ & - & $0.8 \pm 0.02$ \\
\hline & & 20 & $365.6 \pm 20.86^{\dagger}$ & $473.3 \pm 30.26^{\dagger}$ & $356.6 \pm 14.69^{\dagger}$ & $187.0 \pm 8.40^{\dagger}$ & 0 \\
\hline & & 37 & $318.1 \pm 6.43^{\dagger}$ & $453.0 \pm 11.35^{\dagger}$ & $234.2 \pm 22.21$ & $115.0 \pm 2.41$ & 0 \\
\hline & & 60 & $429.7 \pm 7.10$ & $586.7 \pm 23.00$ & $353.1 \pm 27.53$ & $252.3 \pm 18.39$ & 0 \\
\hline \multirow[t]{4}{*}{$\mathrm{A}-\mathrm{NiTi}$} & OPTI & 0 & $110.2 \pm 5.44$ & $144.1 \pm 6.72$ & - & - & $1.6 \pm 0.04$ \\
\hline & & 20 & $308.8 \pm 5.44$ & $378.9 \pm 8.94$ & $167.6 \pm 9.19$ & $133.9 \pm 8.60$ & 0 \\
\hline & & 37 & $350.3 \pm 28.69$ & $416.0 \pm 21.87$ & $218.6 \pm 13.37$ & $160.7 \pm 20.02$ & 0 \\
\hline & & $60^{*}$ & $588.2 \pm 2.46$ & $596.5 \pm 8.45$ & $479.2 \pm 12.09$ & $351.2 \pm 22.79$ & 0 \\
\hline \multirow[t]{4}{*}{$\mathrm{T}-\mathrm{NiTi}$} & NEO & 0 & $22.7 \pm 3.21$ & $56.3 \pm 2.82$ & - & - & $1.9 \pm 0.01$ \\
\hline & & 20 & $98.8 \pm 5.95$ & $112.0 \pm 4.86$ & - & - & $1.7 \pm 0.01$ \\
\hline & & 37 & $254.6 \pm 2.07$ & $299.2 \pm 4.15$ & $42.9 \pm 4.44$ & $29.2 \pm 2.64$ & 0 \\
\hline & & 60 & $124.2 \pm 11.80$ & $136.5 \pm 11.84$ & - & - & $1.7 \pm 0.03$ \\
\hline
\end{tabular}

ANOVA test was done. ${ }^{*}$ Means $p<0.01$. The four force change points and residual deflection were measured. $\alpha$, Martensite transformation start point; $\beta$, martensite transformation finish point; $\gamma$, austenite re-transformation start point; $\delta$, austenite re-transformation finish point; $\sigma$, residual deflection value at load reached zero in the unloading; M-NiTi, work-hardened martensitic type; A-NiTi, super-elastic austenitic type; T-NiTi, thermodynamic type; -, not-measurable parameters; ${ }^{\dagger}$ No discernible plateau.

except at $0^{\circ} \mathrm{C}$ (Fig $2 \mathrm{~B}$ and Table 3 ). Since $\mathrm{A}_{\mathrm{f}}$ of OPTI is $19.7^{\circ} \mathrm{C}$ (Table 2), the phases at 20,37 and $60^{\circ} \mathrm{C}$ may be austenite. The position of the hysteresis loop at $60^{\circ} \mathrm{C}$ (Fig 2B) indicates that the load increased according to the increase in temperature $(p<0.01$, Table 3$)$. The residual deflection at $0^{\circ} \mathrm{C}(\delta=01.6 \pm$ 0.04 , Table 3) might imply the existence of deformation in the martensite structure.

NEO (T-NiTi type) exhibited superelasticity behavior only at $37^{\circ} \mathrm{C}$ (Fig $2 \mathrm{C}$ and Table 3). Since $37^{\circ} \mathrm{C}$ falls above the $\mathrm{A}_{\mathrm{f}}$ of NEO $\left(24.6^{\circ} \mathrm{C}\right.$, Table 2$)$, the phase at $37^{\circ} \mathrm{C}$ may be austenite and the mechanical behavior is associated with formation of stress-induced martensite upon loading and by reverse transformation upon unloading. A partial recovery at $0^{\circ} \mathrm{C}$ and $20^{\circ} \mathrm{C}(\delta=$ $1.9 \pm 0.01, \delta=1.7 \pm 0.01$, respectively, Table 3 ) indicates that the residual stress remained within the wire and that the reverse transformation did not occur completely during unloading. A residual deflection at $60^{\circ} \mathrm{C}$ was also observed $(\delta=1.7 \pm 0.03$, Table 3$)$.

\section{Microstructure examination}

In NC (M-NiTi type), a wavy pattern like striated band was not identified, but a deformation line made by a work-hardening process was observed (Fig 3A). The stabilized work-hardened martensite plate, which might not undergo total retransformation, was observed in NC (M-NiTi type).

In OPTI (A-NiTi type), a wavy pattern like striated band was obvious (Fig 3B). NEO (T-NiTi type) showed evenly dispersed non-metallic inclusions and holes in the NiTi matrix (Fig 3C). Both OPTI (A-NiTi type) and NEO (T-NiTi type) showed mixed structures with a martensite plate in an austenite matrix (Fig 3B and C).

XDR analysis

For NC (M-NiTi type), the peak change could not be clearly analyzed due to the eccentric preferred orientation produced by work-hardening (Fig 4A).

The mixed pattern of a strong peak for austenite (PA, 110) and a weak peak for martensite (PM, 002) 

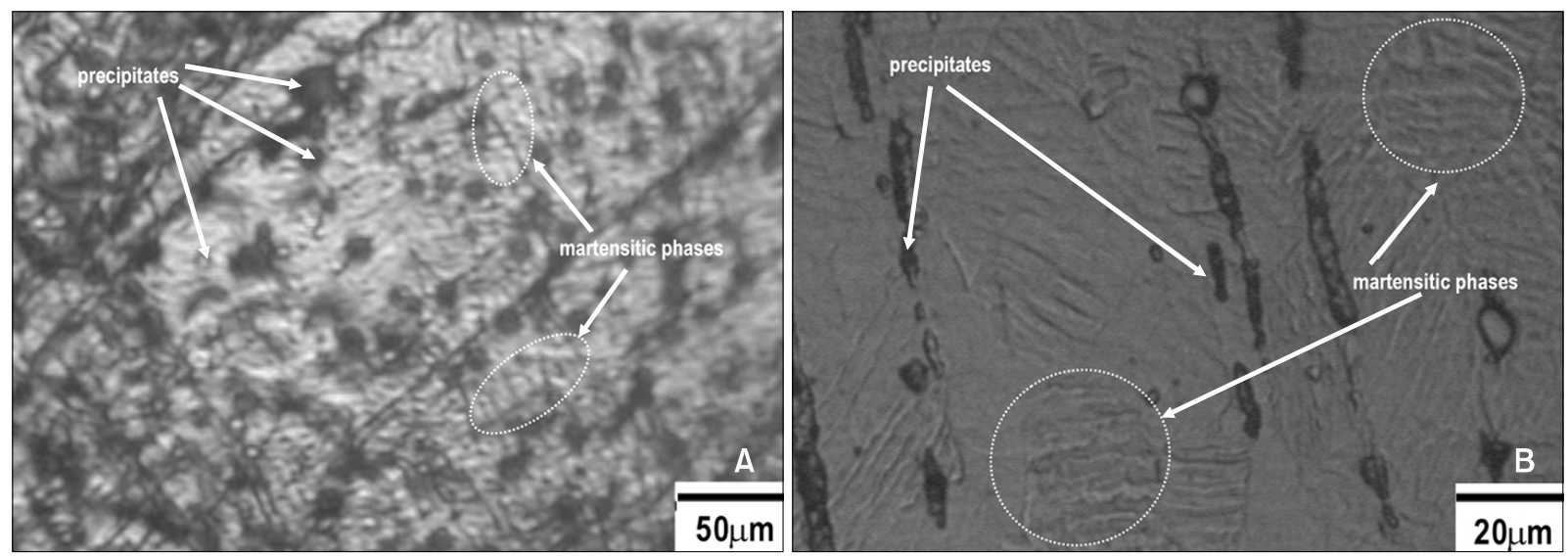

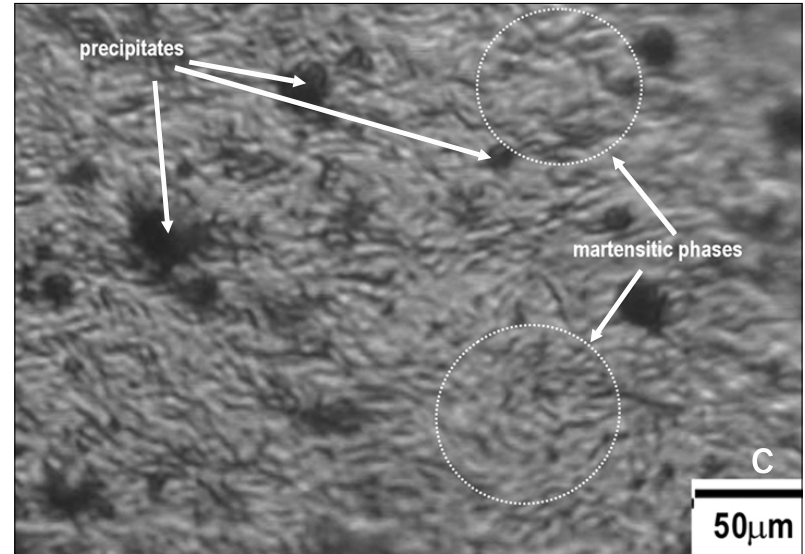

was observed in OPTI (A-NiTi type, Fig 4B). The PM (002) did not become obvious when the temperature decreased to $-20^{\circ} \mathrm{C}$ (Fig 4B).

In NEO (T-NiTi type), there was a mixed pattern of strong PA (110) and mild PM (002) at $5^{\circ} \mathrm{C}$ (Fig 4C). However, the finding that relatively stronger PM (002) and weaker PA (110) existed at $-20^{\circ} \mathrm{C}$ than at 5 and $25^{\circ} \mathrm{C}$ (Fig 4C) indicates that even at a temperature below Mf, T-NiTi wire appeared to have a two-phase structure, not a single crystal structure of martensite. The PM (002) gradually disappeared when the temperature was increased above $25^{\circ} \mathrm{C}$ (Fig $4 \mathrm{C}$ ).

The peak width is an indication for degree of cold work. Compared with full width at half height (FWHH) of the PA (110) peak, NC (M-NiTi type) exhibited a wider peak (more cold work) than either NEO (T-NiTi type) or OPTI (A-NiTi type) (Fig 5).
Fig 3. Optical micrographs of the nickel-titanium wires at room temperature. A, NC (M-NiTi type); B, OPTI (A-NiTi type); C, NEO (T-NiTi type).

\section{DISCUSSION}

DSC and XRD analyses can provide useful information about the phase transformation and microstructure which are related with the mechanical properties of the NiTi wires. ${ }^{11,15-17}$ Since the transformation temperature of NiTi wires, $A_{f}$ and $M_{s}$, are critical factors in their transformation behavior, ${ }^{18}$ it is important to choose an alloy with the correct $\mathrm{A}_{\mathrm{f}}$ (for example, less than $37^{\circ} \mathrm{C}$ ) to be clinically relevant. In this study, $\mathrm{A}_{\mathrm{f}}$ of NC (M-NiTi type, $52.4^{\circ} \mathrm{C}$, Table 2) determined by DSC analysis seems to be too high for clinical use. Since the heating DSC curves suggest that NEO (TNiTi type) and OPTI (A-NiTi type) are completely austenitic in an oral environment (Fig 1), NEO and OPTI could be considered to act as superelastic wires.

Since the two endothermic peaks in the heating curves of OPTI and NEO (Fig 1) means an existence of $\mathrm{R}$ phase, differences in the DSC curves and XRD 
A

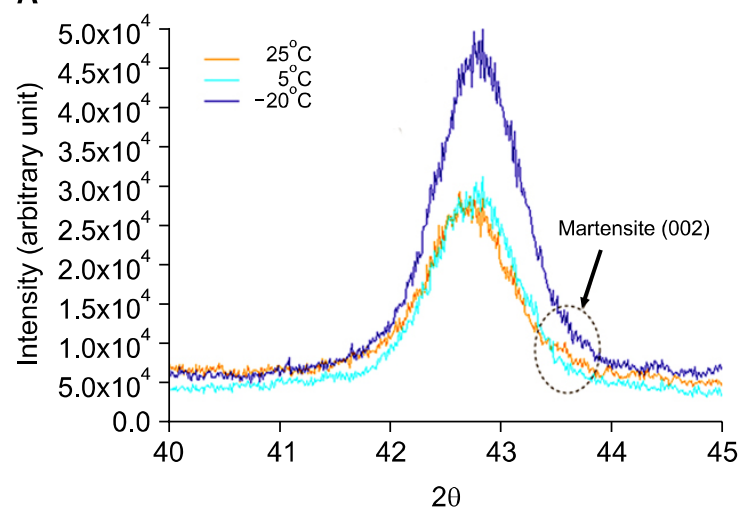

B

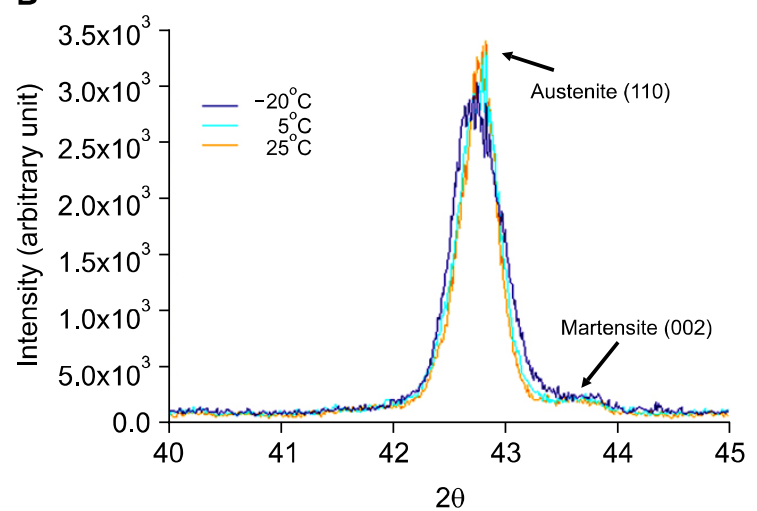

C

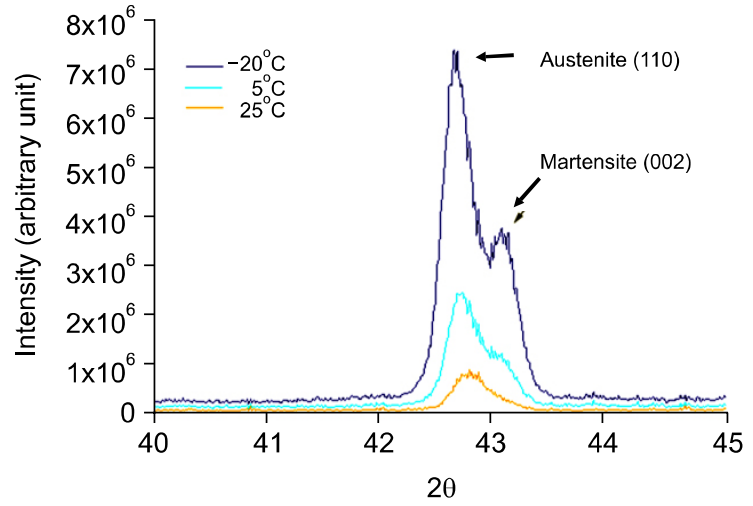

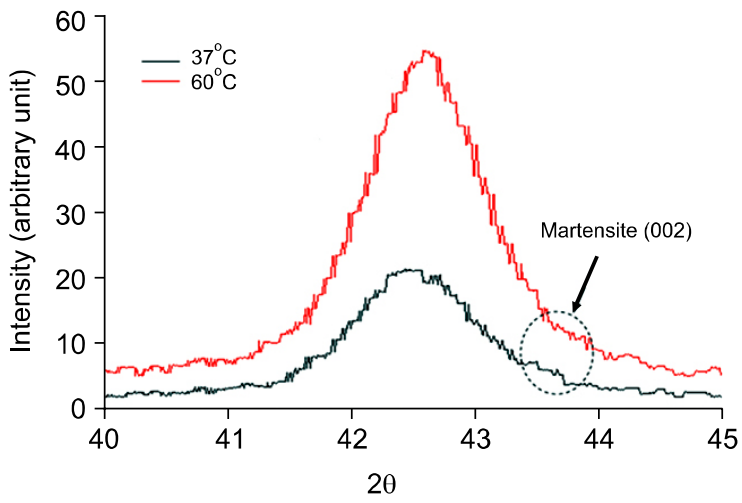
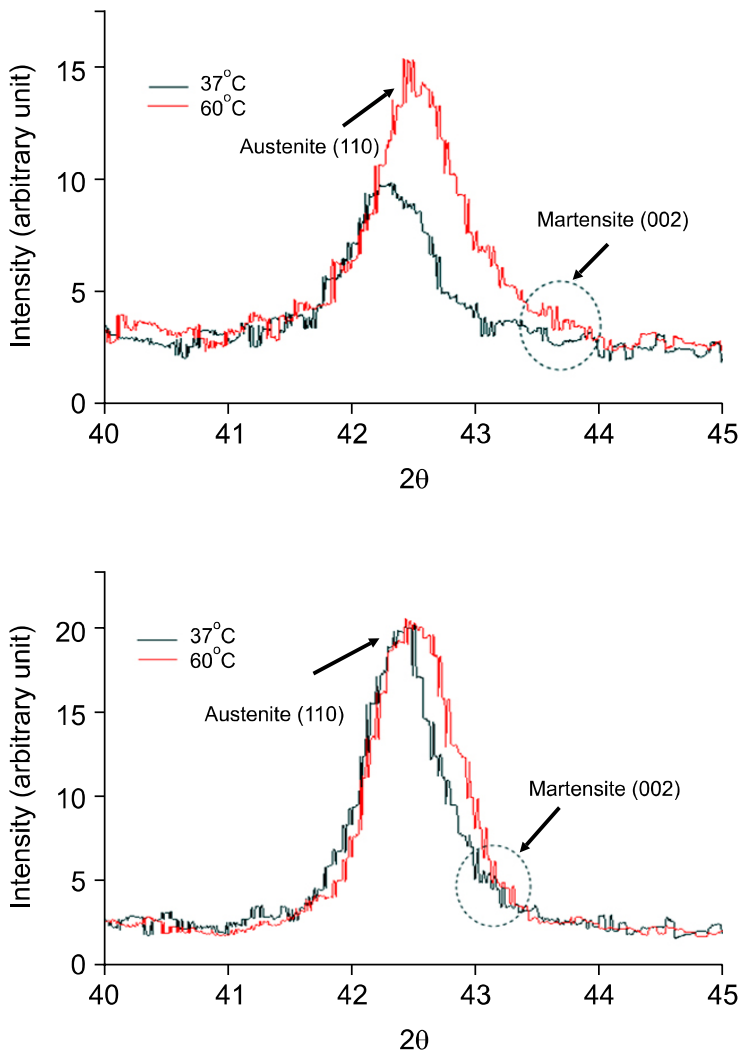

Fig 4. X-ray diffraction patterns of the nickel-titanium wires at various temperatures. A, NC (M-NiTi type); B, OPTI (A-NiTi type); C, NEO (T-NiTi type).

analyses among the three types of NiTi wires might be explained by the influence of the interposition of the R-phase in NEO and OPTI wires (Figs 1, 4 and 5 and Table 2).

The deformation temperatures are divided into four temperature regions; $\mathrm{T}<\mathrm{M}_{\mathrm{s}}, \mathrm{M}_{\mathrm{s}}<\mathrm{T}<\mathrm{A}_{\mathrm{f}}, \mathrm{A}_{\mathrm{f}}<$ $\mathrm{T}<\mathrm{T}_{\mathrm{d}}$ and $\mathrm{T}_{\mathrm{d}}<\mathrm{T}$ (where $\mathrm{T}_{\mathrm{d}}$ represents the critical temperature where the plastic deformation by dislocation motion starts). The common features of the curves in Fig 2 are the presence of a residual deflection after unloading at $0^{\circ} \mathrm{C}\left(\mathrm{T}<\mathrm{M}_{\mathrm{s}}\right)$, and the perfect recovery of the deflection at $37^{\circ} \mathrm{C}$ in all samples and $60^{\circ} \mathrm{C}\left(\mathrm{T}>\mathrm{M}_{\mathrm{s}}\right)$ in OPTI (A-NiTi type) and NC (M-NiTi type). At $60^{\circ} \mathrm{C}$, martensite re-transformation 


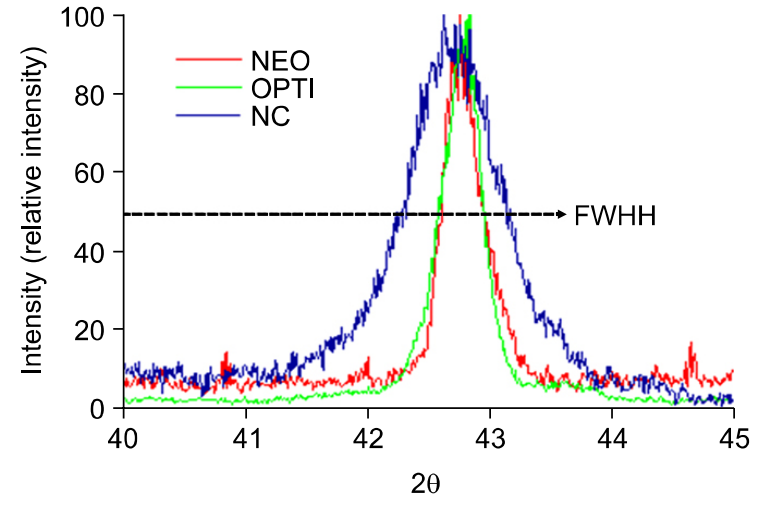

Fig 5. X-ray diffraction patterns of the nickel-titanium wires at room temperature. NC, M-NiTi type; OPTI, A-NiTi type; NEO, T-NiTi type. FWHH means full width at half height.

appears to be inhibited by the plastic deformation induced by dislocation in NEO (T-NiTi type) (Fig 2 and Tables 2 and 3).

At the temperatures below $\mathrm{M}_{\mathrm{f}}$, the martensite crystal is attained by continuous growth of the martensite plates and the nucleation of new martensite plates. ${ }^{2}$ When the specimen is heated, the martensite plates revert completely to the parent phase and to the original lattice orientation. ${ }^{2,5}$ Another mechanism for achieving crystallographic reversibility is with the use of the stress-induced martensite phenomena. ${ }^{19}$ The mechanical behavior of OPTI (A-NiTi type) at room temperature (Fig 1B) is associated with the formation of stress-induced martensite upon loading and by reverse transformation on unloading. In general, the martensite is induced when $\mathrm{T}<\mathrm{M}_{\mathrm{s}}$ or the boundaries between the martensites or internal twin boundaries begin to move. As the environmental temperature is elevated, the critical load of stress-induced martensite transformation is also increased. This is because the parent phase is more stable at high environmental temperatures. There is a negative linear relationship between the stress and the temperature with respect to the induction of martensite; a decrease in temperature is equivalent to an increase in stress. ${ }^{20,21}$ According to this relationship, the critical stress to induce martensite in a low $A_{f}$ wire is higher than that in a high $A_{f}$ wire. Therefore, the load, $\alpha$, in Ni-Ti wire with a low $\mathrm{A}_{\mathrm{f}}$ (OPTI, A-NiTi type, $19.7^{\circ} \mathrm{C}$, Table 2$)$ would be relatively high $(p<$
0.01, Table 3).

The mean mouth temperature throughout a 24-hour period is known to be around $35^{\circ} \mathrm{C}$ with variation according to time and location. ${ }^{21-23}$ Since a transient change in the oral temperature associated with ingestion of cold/hot food can lead to marked changes in the phase transformation of NiTi wires, difference in force magnitude of the NiTi wires can cause irreversible tissue damage, extensive hyalinization of the periodontal ligament and root resorption or retardation of tooth movement. ${ }^{16,24}$ Therefore, the mechanical properties of these wires need to be measured in clinical temperature ranges. ${ }^{5,25-34}$ The results of this study clearly indicate that the mechanical properties of NiTi wires are substantially affected by temperature changes (Table 3). When the temperature was varied between 0 and $60^{\circ} \mathrm{C}$, the load ranged between 22.7 and 124.2 gf for NEO (T-NiTi type), between 110.7 and 588.2 gf for OPTI (A-NiTi type), and between 79.8 and $429.7 \mathrm{gf}$ for NC (M-NiTi type) (Table 3). The broad force range according to temperature change in OPTI (ANiTi type) and NC (M-NiTi type) compared with NEO (M-NiTi type) (Table 3) might not guarantee a light and constant force for effective and efficient tooth movement.

Although the results of this study may explain the reason why commercially available $\mathrm{M}$-, A- and T-NiTi wires exhibited complicated and unexpected mechanical properties according to temperature change, the details of the transformation behavior and mechanical properties of NiTi wires cannot be fully described. Therefore, further studies concerning the relationship among microstructure, phase transformation behavior and mechanical properties of NiTi wires will be needed.

\section{CONCLUSION}

1. NEO and OPTI showed better mechanical properties and phase transformation behavior than NC.

2. The mechanical and thermal behaviors of NiTi wire cannot be completely explained by the expected phase distribution and phase ratio from TTR because NiTi alloy has complicated martensite variants and independent phase transformation induced by 
heat and stress.

- 국문초록 -

$$
\begin{gathered}
\text { 니켈-타이타늄 호선의 상전이 온도 범위와 } \\
\text { 상전이 행동 비교 } \\
\text { 이유현 }{ }^{a} \cdot \text { 임범순 }^{b} \cdot \text { 이용근 }^{c} \cdot \text { 김철위 }^{d} \cdot \text { 백승학 }^{e}
\end{gathered}
$$

본 연구의 목적은 martensitic (M-NiTi), austenitic (A-NiTi) 및 thermodynamic nickel-titanium wire (T-NiTi)의 물리적 특 징과 상전이 정도를 평가하는 것이다. 재료는 $0.016 \times 0.022$ inch의 M-NiTi (Nitinol Classic, NC), A-NiTi (Optimalloy, $\mathrm{OPTI}$ )와 T-NiTi (Neo-Sentalloy, NEO)이었으며, differential scanning calorimetry (DSC), 3점굽힘실험, X-ray diffraction (XRD), 미세구조 분석을 시행하였으며, ANOVA test로 통계 처리하였다. DSC분석 결과 OPTI와 NEO는 heating curve 에서 2 개의 peak, cooling curve에서 1 개의 peak를 보였고, $\mathrm{NC}$ 는 heating과 cooling curve에서 1 개의 넓고 약한 peak를 보였다. Austenite finishing $\left(\mathrm{A}_{\mathrm{f}}\right)$ 온도는 $\mathrm{OPTI} 19.7^{\circ} \mathrm{C}, \mathrm{NEO}$ $24.6^{\circ} \mathrm{C}, \mathrm{NC} 52.4^{\circ} \mathrm{C}$ 였다. 3점굽힘실험 결과 $\mathrm{NC}, \mathrm{OPTI}, \mathrm{NEO}$ 모두 residual deflection을 보였으며, NC와 OPTI의 load range가 NEO보다 컸다. XRD와 미세구조 분석결과 OPTI와 $\mathrm{NEO}$ 는 Martensite finishing $\left(\mathrm{M}_{\mathrm{f}}\right)$ 에서 martensite와 austenite가 섞여 있음이 관찰되었다. NEO와 OPTI는 NC보다 개선 된 물리적 특징과 상전이 행태를 보였다. $\mathrm{NiTi}$ 호선의 물리 적, 온도에 따른 행태는 예상되었던 상전이 정도에 의해 완 벽하게 설명되지 않았으며, 그 이유는 복잡한 martensite variants의 존재와 열과 stress에 의해 유도된 독립적인 상전 이에 기인한다고 생각된다.

\section{주요 단어: Transition temperature range, Phase trans- formation, $\mathrm{Ni}$-Ti wires}

\section{REFERENCES}

1. Sakima MT, Dalstra M, Melsen B. How does temperature influence the properties of rectangular nickel-titanium wires? Eur J Orthod 2006;28:282-91.

2. Gil FJ, Planell JA. Shape memory alloys for medical applications. Proc Inst Mech Eng [H] 1998;212:473-88.

3. Khier SE, Brantley WA, Fournelle RA. Bending properties of superelastic and nonsuperelastic nickel-titanium orthodontic wires. Am J Orthod Dentofacial Orthop 1991;99:310-8.

4. Ren CC, Bai YX, Wang HM, Zheng YF, Li S. Phase transformation analysis of varied nickel-titanium orthodontic wires. Chin Med J (Engl) 2008;121:2060-4.
5. Meling TR, Ødegaard J. The effect of temperature on the elastic responses to longitudinal torsion of rectangular nickel titanium archwires. Angle Orthod 1998;68:357-68.

6. Meling TR, Ødegaard J. The effect of short-term temperature changes on the mechanical properties of rectangular nickel titanium archwires tested in torsion. Angle Orthod 1998;68:36976.

7. Kusy RP, Wilson TW. Dynamic mechanical properties of straight titanium alloy arch wires. Dent Mater 1990;6:228-36.

8. Santoro M, Beshers DN. Nickel-titanium alloys: stress-related temperature transitional range. Am J Orthod Dentofacial Orthop 2000;118:685-92.

9. Brantley WA, Iijima M, Grentzer TH. Temperature-modulated DSC provides new insight about nickel-titanium wire transformations. Am J Orthod Dentofacial Orthop 2003;124:387-94.

10. Iijima M, Ohno H, Kawashima I, Endo K, Mizoguchi I. Mechanical behavior at different temperatures and stresses for superelastic nickel-titanium orthodontic wires having different transformation temperatures. Dent Mater 2002;18:88-93.

11. Bradley TG, Brantley WA, Culbertson BM. Differential scanning calorimetry (DSC) analyses of superelastic and nonsuperelastic nickel-titanium orthodontic wires. Am J Orthod Dentofacial Orthop 1996;109:589-97.

12. Burstone CJ, Qin B, Morton JY. Chinese NiTi wire - a new orthodontic alloy. Am J Orthod 1985;87:445-52.

13. Miura F, Mogi M, Ohura Y, Hamanaka H. The super-elastic property of the Japanese NiTi alloy wire for use in orthodontics. Am J Orthod Dentofacial Orthop 1986;90:1-10.

14. Brantley WA, Guo W, Clark WA, Iijima M. Microstructuralstudies of 35 degrees $\mathrm{C}$ copper $\mathrm{Ni}-\mathrm{Ti}$ orthodontic wire and TEM confirmation of low-temperature martensite transformation. Dent Mater 2008;24:204-10.

15. Iijima M, Ohno H, Kawashima I, Endo K, Brantley WA, Mizoguchi I. Micro X-ray diffraction study of superelastic nickel-titanium orthodontic wires at different temperatures and stresses. Biomaterials 2002;23:1769-74.

16. Thayer TA, Bagby MD, Moore RN, DeAngelis RJ. X-ray diffraction of nitinol orthodontic arch wires. Am J Orthod Dentofacial Orthop 1995;107:604-12.

17. Brantley WA, Iijima M, Grentzer TH. Temperature-modulated DSC provides new insight about nickel-titanium wires transformations. Am J Orthod Dentofacial Orthop 2003;124:387-94.

18. Barwart O, Rollinger JM, Burger A. An evaluation of the transition temperature range of superelastic orthodontic NiTi springs using differential scanning calorimetry. Eur J Orthod 1999;21:497-502.

19. Rondelli G, Vicentini B. Evaluation by electrochemical tests of the passive film stability of equiatomic Ni-Ti alloy also in presence of stress-induced martensite. J Biomed Mater Res 2000;51:47-54.

20. Airoldi G, Riva G. Innovative materials: the NiTi alloys in orthodontics. Biomed Mater Eng 1996;6:299-305.

21. Airoldi G, Riva G, Vanelli M, Filippi V, Garattini G. Oral environment temperature changes induced by cold/hot liquid intake. Am J Orthod Dentofacial Orthop 1997;112:58-63.

22. Volchansky A, Cleaton-Jones P. Variations in oral temperature. J Oral Rehabil 1994;21:605-11.

23. Moore R J, Watts JT, Hood JA, Burritt DJ. Intra-oral temper- 
ature variation over 24 hours. Eur J Orthod 1999;21:249-61.

24. Dalstra M, Melsen B. Does the transition temperature of $\mathrm{Cu}-\mathrm{NiTi}$ archwires affect the amount of tooth movement during alignment? Orthod Craniofac Res 2004;7:21-5.

25. Yoneyama T, Doi H, Hamanaka H, Yamamoto M, Kuroda T. Bending properties and transformation temperatures of heattreated Ni-Ti alloy wire for orthodontic appliances. J Biomed Mater Res 1993;27:399-402.

26. Tonner RI, Waters NE. The characteristics of super-elastic $\mathrm{Ni}$-Ti wires in three-point bending. Part I: the effect of temperature. Eur J Orthod 1994;16:409-19.

27. Bishara SE, Winterbottom JM, Sulieman AA, Rim K, Jakobsen JR. Comparisons of the thermodynamic properties of three nickel-titanium orthodontic archwires. Angle Orthod 1995;65: 117-22.

28. Filleul MP, Jordan L. Torsional properties of Ni-Ti and copper Ni-Ti wires: the effect of temperature on physical properties. Eur J Orthod 1997;19:637-46.

29. Oltjen JM, Duncanson MG Jr, Ghosh J, Nanda RS, Currier GF. Stiffness-deflection behavior of selected orthodontic wires.
Angle Orthod 1997;67:209-18.

30. Nakano H, Satoh K, Norris R, Jin T, Kamegai T, Ishikawa F, et al. Mechanical properties of several nickel-titanium alloy wires in three-point bending tests. Am J Orthod Dentofacial Orthop 1999;115:390-5.

31. Gurgel JA, Kerr S, Powers JM, LeCrone V. Force-deflection properties of superelastic nickel-titanium archwires. Am J Orthod Dentofacial Orthop 2001;120:378-82.

32. Wilkinson PD, Dysart PS, Hood JA, Herbison GP. Load-deflection characteristics of superelastic nickel-titanium orthodontic wires. Am J Orthod Dentofacial Orthop 2002;121:48395.

33. Fischer-Brandies H, Es-Souni M, Kock N, Raetzke K, Bock O. Transformation behavior, chemical composition, surface topography and bending properties of five selected $0.016^{\prime \prime} \times$ 0.022" NiTi archwires. J Orofac Orthop 2003;64:88-99.

34. Parvizi F, Rock WP. The load/deflection characteristics of thermally activated orthodontic archwires. Eur J Orthod 2003;25: 417-21. 